edifice, and the spray at times going over its summit before the final catastrophe. Huge masses of masonry now lie about in strange confusion to mark the spot where once stood this famous church; but ere long probably every vestige of it will be obliterated.

NoRwich.

\title{
A GLACIAL COMMITTEE FOR NORTH AMERICA AND EUROPE.
}

Sin,- The following are the names of members of the International Glacial Committee created at Zurich last summer. The list is to be completed by representatives of Russia and Italy.

\begin{tabular}{|c|c|c|}
\hline Countries. & Names. & ADDREss. \\
\hline $\begin{array}{l}\text { United States, } N . \text { America } \\
\text { Austria } \\
\text { Germany }\end{array}$ & 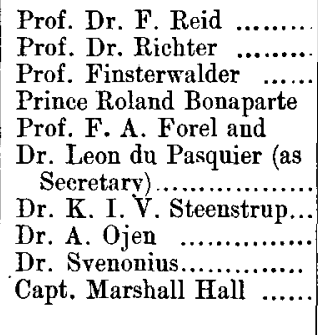 & $\begin{array}{l}\text { Baltimore. } \\
\text { Graz. } \\
\text { Munich. } \\
\text { Paris. } \\
\text { Morges. } \\
\text { Copenhagen } \\
\text { Christiania } \\
\text { Stockholm } \\
\text { Easterton Lodge, Park- } \\
\text { stone, Dorset. }\end{array}$ \\
\hline
\end{tabular}

The committe has powers to adopt its own organization, and is to report to the General Committee of the Congress, which was invited by the late Tsar to meet at St. Petersburg. Prof. Forel is the Organizing Secretary.

Marshall Hall. $_{\text {al }}$

Easterton Lodgr, Parkstonk, Dorset.

Mr. Robert Etheridge, Jun., formerly of the Geological Department in the British Museum (Natural History), and who for the last few years has occupied the position of Palæontologist to the Museum and the Geological Survey of New South Wales. Sydney, was appointed on the 1st of January to the office of Curator of the Australian Museum, Sydney, N.S.W., in the place of Mr. E. P. Ramsay, F.L.S., F.G.S., who has retired, having been in failing health for some years. Mr. R. Etheridge, jun., has distinguished himself both in this country and in Australia by his scientific researches, and has just been awarded the Clarke Medal from the Royal Society of New South Wales for his contributions to Australian geology.

With deep regret we have to record the death of Mr. J. W. Hunkr, F.R.S., Foreign Secretary of the Geological Society of London, which took place on February 19th, after a brief illness. In addition to his great scientific abilities, and his distinguished position as a surgeon, he bad endeared bimself to a wide circle of friends by his amiable personal qualities. We hope to give a suitable notice of his scientific work in the April Number. 